\title{
An investigation of thiol/disulfide homeostasis and ischemia-modified albumin levels to assess the oxidative stress in dogs with canine distemper
}

\author{
Şükrü Değirmençay ${ }^{1 *}$, Güzin Çamkerten ${ }^{2}$, İlker Çamkerten ${ }^{3}$, and M. Sinan Aktaş ${ }^{1}$ \\ ${ }^{1}$ Department of Internal Medicine, Faculty of Veterinary Medicine, Atatürk University, Erzurum, Turkey \\ ${ }^{2}$ Aksaray Technical Sciences Vocational School, Aksaray University, Aksaray, Turkey \\ ${ }^{3}$ Department of Internal Medicine, Faculty of Veterinary Medicine, Aksaray University, Aksaray, Turkey
}

\begin{abstract}
DEĞIRMENÇAY, Ş., G. ÇAMKERTEN, İ. ÇAMKERTEN, M. S. AKTAÇ: An investigation of thiol/disulfide homeostasis and ischemia-modified albumin levels to assess the oxidative stress in dogs with canine distemper. Vet. arhiv 91, 39-49, 2021.
\end{abstract}

\section{ABSTRACT}

This study aimed to investigate the diagnostic value of thiol/disulfide homeostasis (TDH) and ischemia-modified albumin (IMA) levels in evaluating oxidative stress in dogs with canine distemper. The study materials consisted of 24 cross-breed dogs: 18 dogs with canine distemper (CD group) and 6 healthy dogs as the control. Blood samples for analysis of antioxidant-oxidant parameters were taken from both groups. In addition to TDH parameters (native thiol [NT], total thiol [TT], and disulfide [Ds] levels and Ds/NT, Ds/TT, and NT/TT ratios), IMA and albumin (ALB) levels were also determined in the blood serum of the groups. The IMA levels of the CD group were significantly higher than the control group $(\mathrm{P}<0.05)$. Antioxidant parameters $(\mathrm{NT}, \mathrm{TT})$ and oxidant parameters $(\mathrm{Ds}, \mathrm{Ds} / \mathrm{NT}$, and Ds/TT) both exhibited a significant positive correlation among themselves $(\mathrm{P}<0.01)$. The areas under the ROC curve of IMA, Ds/ NT, and Ds/TT were $0.78,0.62$, and 0.62 respectively. The high levels of IMA, Ds, Ds/NT, and Ds/TT and low levels of NT, TT, NT/TT and ALB in dogs with canine distemper can be used to assess the oxidative stress caused by the disease. Overall, the diagnostic performances of IMA, Ds/NT, and Ds/TT for detection of increased oxidative stress were similar, but IMA was superior.

Key words: canine distemper; oxidative stress; thiol/disulfide homeostasis; ischemia-modified albumin

\section{Introduction}

Canine distemper is an infectious, multisystemic and fatal disease of dogs caused by the canine distemper virus (CDV), a paramyxovirus of the genus Morbillivirus (BEINEKE et al., 2009; CARPENTER et al., 1998). The disease occurs most commonly in young dogs (3-6 months old) (GREENE and APPEL, 1998; MARTELLA et al., 2008; TAYLOR, 2009) and it is mostly characterized by a biphasic fever (SUMMERS and
APPEL, 1994; THULIN et al., 1992; WRIGHT et al., 1974), gastrointestinal, respiratory and nervous system signs (WILLIAMS, 2001). In this context, the clinical findings may include leukopenia (especially lymphopenia), serous nasal discharge, mucopurulent ocular discharge, lethargy, myoclonus, anorexia and secondary bacterial infections (WILLIAMS, 2001).

\footnotetext{
*Corresponding author:

Assist. Prof. Şükrü Değirmençay, PhD, DVM, Atatürk University, Faculty of Veterinary Medicine, Department of Internal Medicine, Erzurum, Turkey, Fax: +90 442231 7244; E-mail: s.degirmencay@atauni.edu.tr
} 
Oxidative stress plays an indicative role in the pathogenesis of many diseases and inflammatory processes. It occurs when redox homeostasis changes in the cell, either due to the overproduction of reactive oxygen species (ROS) or the lack of an antioxidant system (SEMBA and TANG, 1999). Total oxidant and antioxidant capacity, ceruloplasmin and ischemia-modified albumin (IMA) are some of the important biomarkers of oxidative stress (ATES et al., 2016; ELMAS et al., 2017; HANIKOGLU et al., 2016). EREL and NESELIOGLU (2014) have developed a new, fully-automated method in the evaluation of TDH as a new marker of oxidative stress. Plasma thiols have antioxidant and pro-oxidant features, and contain a sulfhydryl group (-SH) (ATMACA, 2004; EREL and NESELIOGLU, 2014). The plasma thiol pool consists of albumin, protein thiols and low molecular weight thiols (cysteine, cysteinylglycine, glutathione, homocysteine and p-glutamylcysteine) (ATMACA, 2004). The dynamic TDH in the organism can be affected by oxidative stress in disease processes. When thiol compounds undergo oxidation reactions, they form disulfide bonds. Therefore, increasing oxidative stress has an impact on the redox state, which can be explained by the metabolization of thiol groups into disulfide groups (ASOĞLU et al., 2018).

The dynamic TDH has a critical role in metabolism and homeostasis (BISWAS et al., 2006; CIRCU and AW, 2010; EREL and NESELIOGLU, 2014). The parameters of this homeostasis include native thiol (NT) and total thiol (TT); disulfide (Ds); disulfide/native thiol (Ds/NT), native thiol/ total thiol (NT/TT), and disulfide/total thiol (Ds/ TT) ratios (ELMAS et al., 2017). TDH levels are measured one-by-one and cumulatively using a novel and automated method which allows a complete evaluation of the oxidant and antioxidant status (OZLER et al., 2015). The antioxidant effect of TDH has a significant function in enzymatic reactions, signal transmission, detoxification, transcription and apoptosis mechanisms. Under normal conditions, TDH has a dynamic structure and it may be adversely affected by pathologies that cause an increase in the level of oxidative stress (EREL and NESELIOGLU, 2014; TURELL et al., 2013). The thiol disulfide ratio has emerged as a new biomarker used in human patients with diabetes, cardiovascular diseases, cancer and some other diseases (ATES et al., 2016; ELMAS et al., 2017; HANIKOGLU et al., 2016). In veterinary medicine, oxidative stress has also been reported to take part in the pathogenesis of various infections of dogs, such as Babesia gibsoni (MURASE et al.,1996), Leishmaniasis (BİLDIK et al., 2004), concurrent infection of Babesiosis and Ehrlichiosis (KUMAR et al., 2006), canine parvoviral enteritis (PANDA et al., 2009) and canine distemper (KARADENIZ et al., 2008). However, the rate of thiol-disulfide, a novel biomarker for oxidative stress, is a recently studied parameter in the field of veterinary medicine.

Albumin, the most abundant protein in the body, is in charge of the elimination of ROS (LIPPI and MONTAGNANA, 2009). KINOSHITA et al. (2017) reported that increased oxidative stress was associated with decreased albumin levels. When ischemia is present, changes in the amino acid sequence occur at the N-terminus of the albumin, and the new emerging protein is called ischemiamodified albumin (IMA). The increase in ROS, ischemia, or the hypoxic process is closely linked to IMA (LIPPI and MONTAGNANA, 2009).

The aim of this study was to evaluate the oxidative stress level in dogs with canine distemper in terms of thiol-disulfide ratio and IMA. A further aim was to investigate the compatibility of thioldisulfide balance with IMA and albumin in the evaluation of oxidative stress. This study was also designed to determine for the first time how successful the thiol-disulfide ratio is as an indicator of oxidative stress in dogs with canine distemper.

\section{Materials and methods}

Animals and protocol design. The study material included 24 dogs of 2 to 6 months old, different breeds and both genders. The dogs were divided into two groups as control and CD groups. Six healthy dogs were included in the control group. These 6 dogs were selected from animals brought by their owners to Atatürk University Faculty of Veterinary Medicine Animal Hospital for a routine health check-up or vaccination. They were considered to 
be healthy on the basis of physical examination, complete blood count findings and the negative result of a CDV Antigen (Ag) rapid test kit (CDV $\mathrm{Ag}$ Antigen Rapid Test $\mathrm{Kit}^{\mathbb{B}}$, Bionote Korea, Cat. No: RG1303DD). The CD group consisted of 18 dogs. The dogs with at least two of these complaints: nasal discharge, ocular discharge, fever, anorexia, and cough, were tested with a CDV antigen $(\mathrm{Ag})$ rapid test kit. Those that were tested positive were included in the CD group. The study was approved by the Atatürk University Faculty of Veterinary Medicine Ethics Committee for compliance with ethical rules (2019/08).

Blood sampling. Blood samples from all the dogs included in this study were taken from the vena cephalica antebrachii and collected into sterile tubes without an anticoagulant (Becton Dickinson Co., USA). After leaving for 1 hour at room temperature for clotting, sera were obtained by centrifugation at $3000 \mathrm{rpm}$ for 10 minutes, and stored at $-80{ }^{\circ} \mathrm{C}$ until they were analysed.

Chemicals used in the assays. Sodium borohydride $\left(\mathrm{NaBH}_{4}\right), 5,5$ '-dithiobis-2-nitrobenzoic acid (DTNB), formaldehyde, cobalt (II) chloride $\left(\mathrm{CoCl}_{2} * 6 \mathrm{H}_{2} \mathrm{O}\right)$ and dithiothreitol (DTT) were acquired from Sigma-Aldrich Chemical Co. (Sigma-Aldrich Chemie $\mathrm{GmbH}$, Riedstrasse 2, Steinheim, Germany).

Thiol-disulfide balance. The thiol-disulfide balance (native thiol [-SH] vs. disulfide [-S-S] alteration) in both groups was determined using the automatic measurement method described by EREL and NESELIOGLU (2014), using a Shimadzu UV-1800 spectrophotometer (Shimadzu Scientific Instruments, Kyoto, Japan) and a Roche Cobas c501 automated analyzer (Roche Diagnostics, Indianapolis, Indiana, United States). Firstly, $\mathrm{NaBH}_{4}$ was used to form free functional thiol groups which were reduced from dynamic disulfide bonds present in the serum samples. To avoid any extra reduction in DTNB and further reduction of the already-formed disulfide bonds, formaldehyde was used to clear away the unused $\mathrm{NaBH}_{4}$ reductant. Following the reaction with DTNB, the thiol groups (including reduced and native ones) were measured spectrophotometrically at $415 \mathrm{~nm}$. Serum TDH values were presented in $\mu \mathrm{mol} / \mathrm{L}$. The following formulas were used to calculate the disulfide concentration and Ds/NT, Ds/TT, and NT/TT percentages:

Disulfide levels $(\mu \mathrm{mol} / \mathrm{L})=($ total thiol- native thiol $) / 2$

Disulfide $/$ native thiol percentage $(\%)=($ disulfide $\times 100) /$ native thiol

Disulfide/total thiol percentage $(\%)=($ disulfide $\times 100) /$ total thiol

Native thiol percentage $(\%) /$ total thiol percentage $(\%)=$ (native thiol $\times 100$ ) / total thiol

Ischemia-modified albumin. Serum ischemiamodified albumin (IMA) level was measured by a method described by DAŞ et al. (2016) based on the spectrophotometric measurement (470 $\mathrm{nm}$ ) of colour obtained as a result of the reaction of albumin-cobalt with DTT. Firstly, the reaction was carried out by adding $50 \mu \mathrm{L} 0.1 \%$ cobalt (II) chloride $\left(\mathrm{CoCl}_{2} * 6 \mathrm{H}_{2} \mathrm{O}\right)$ to the serum specimens. This mixture was left for 10 minutes of incubation to allow for albumin cobalt binding. Then $50 \mu \mathrm{L} 1.5$ $\mathrm{mg} / \mathrm{mL}$ DTT was added and left for 2 minutes for incubation. To reduce the binding capacity, $1 \mu \mathrm{L}$ of a $0.9 \%$ sodium chloride $(\mathrm{NaCl})$ solution was added. The blank was prepared following the same order with distilled water instead of DTT. The absorbance of samples was measured at $470 \mathrm{~nm}$ using a Shimadzu UV-1800 spectrophotometer (Shimadzu Scientific Instruments, Kyoto, Japan). The results were expressed as absorbance units (ABSU).

Albumin. Albumin levels (g/L) were measured with a clinical biochemistry autoanalyzer, Roche Cobas c501 (Roche Diagnostics, Indianapolis, Indiana, United States).

Statistical analysis. Statistical analyses were performed using The Statistical Package for the Social Sciences (SPSS) 20.0 program (SPSS Inc., Chicago, IL, USA). The normality of data distribution for each parameter was evaluated using a Shapiro-Wilk test. The independent sample t-test was used to determine the difference between the groups. The numerical variables were compared on the basis of the Pearson correlation test. Receiver Operating Characteristic (ROC) analysis was employed to determine sensitivity, specificity, and cut-off values. The values obtained were expressed as mean $\pm \mathrm{SD}$. The differences were considered to be significant when $\mathrm{P} \leq 0.05$. 


\section{Results}

The IMA levels of the CD group were significantly higher than the control group $(\mathrm{P}<0.05)$. The Ds levels and Ds/NT and Ds/TT ratios in the $\mathrm{CD}$ group were numerically higher than the control group. The NT, TT, and ALB levels and NT/TT ratio in the $\mathrm{CD}$ group were numerically lower than the control group (Table 1).

Antioxidant parameters (NT and TT) and oxidant parameters (Ds, Ds/NT, and Ds/TT) both exhibited a significant positive correlation among themselves
$(\mathrm{P}<0.01)$ while a significant negative correlation was found between the antioxidant and oxidant parameters $(\mathrm{P}<0.05)($ Table 2$)$. Sensitivity values were NT: $61.1 \%$, TT: $33.3 \%$, Ds levels and NT/TT, Ds/NT and Ds/TT ratios: $55.6 \%$, IMA: $72.2 \%$ and ALB: $83.3 \%$. The areas under the ROC curve of NT, TT, NT/TT, Ds, Ds/NT, Ds/TT, IMA, and ALB were $0.602,0.593,0.62,0.63,062,0.62,0.787$, and 0.671 respectively (Table 3) (Figs 1 and 2).

Table 1. Comparison of thiol/disulfide homeostasis parameters and ischemia-modified albumin and albumin levels of the study and control groups

\begin{tabular}{|l|c|c|c|}
\hline Parameters & Control group & CD group & Test P \\
\hline NT $(\mu \mathrm{mol} / \mathrm{L})$ & $209.75 \pm 49.89$ & $189.43 \pm 38.01$ & $\mathrm{P}=0.305$ \\
\hline TT $(\mu \mathrm{mol} / \mathrm{L})$ & $235.85 \pm 50.31$ & $217.60 \pm 42.00$ & $\mathrm{P}=0.389$ \\
\hline $\mathrm{NT} / \mathrm{TT}(\%)$ & $88.55 \pm 2.59$ & $86.99 \pm 3.66$ & $\mathrm{P}=0.346$ \\
\hline Ds $(\mu \mathrm{mol} / \mathrm{L})$ & $13.05 \pm 1.77$ & $14.08 \pm 4.31$ & $\mathrm{P}=0.418$ \\
\hline Ds/NT $(\%)$ & $6.50 \pm 1.65$ & $7.57 \pm 2.46$ & $\mathrm{P}=0.332$ \\
\hline Ds/TT $(\%)$ & $5.72 \pm 1.30$ & $6.50 \pm 1.83$ & $\mathrm{P}=0.345$ \\
\hline IMA $(\mathrm{ABSU})$ & $1.23 \pm 0.03$ & $1.32 \pm 0.14$ & $\mathbf{P}=\mathbf{0 . 0 1 7}$ \\
\hline ALB $(\mathrm{g} / \mathrm{L})$ & $13.95 \pm 5.01$ & $11.23 \pm 4.20$ & $\mathrm{P}=0.204$ \\
\hline
\end{tabular}

NT - native thiol, TT - total thiol, Ds - disulfide, IMA - ischemia modified albumin, ABSU - absorbance units, ALB - albumin, Data are presented as the mean $\pm \mathrm{SD}, \mathrm{SD}$ - standard deviation.

Table 2. Results of the correlation analyses among THD parameters, IMA and ALB levels

\begin{tabular}{|l|c|c|c|c|c|c|c|c|}
\hline Parameters & NT & TT & NT/TT & Ds & Ds/NT & Ds/TT & IMA & Albumin \\
\hline NT r & 1.000 & $0.986^{* *}$ & $0.419^{*}$ & 0.271 & $-0.428^{*}$ & $-0.420^{*}$ & -0.313 & $0.702^{* *}$ \\
\hline TT r & & 1.000 & 0.264 & $0.429^{*}$ & -0.274 & -0.264 & -0.334 & $0.721^{* *}$ \\
\hline NT/TT r & & & 1.000 & $-0.743^{* *}$ & $-0.998^{* *}$ & $-1.000^{* *}$ & -0.014 & 0.132 \\
\hline Ds r & & & & 1.000 & $0.729^{* *}$ & $0.743^{* *}$ & -0.234 & 0.356 \\
\hline Ds/NT r & & & & & 1.000 & $0.998^{* *}$ & 0.011 & -0.135 \\
\hline Ds/TT r & & & & & & 1.000 & 0.014 & -0.132 \\
\hline IMA r & & & & & & & 1.000 & -0.361 \\
\hline ALB r & & & & & & & & 1.000 \\
\hline
\end{tabular}

NT - native thiol, TT - total thiol, Ds - disulfide, IMA - ischemia-modified albumin, ALB - albumin $\mathrm{r}$ - Pearson correlation coefficient, $* \mathrm{P}<0.05, * * \mathrm{P}<0.01$ 
S. Değirmençay et al.: Thiol/disulfide homeostasis in canine distemper

Table 3. ROC curve analysis of TDH parameters, IMA and ALB levels

\begin{tabular}{|l|c|c|c|c|c|}
\hline Parameters & Area & Cut-off & Sensitivity $(\%)$ & Specificity (\%) & Test P \\
\hline NT $(\mu \mathrm{mol} / \mathrm{L})$ & 0.602 & 190.80 & 61.1 & 66.7 & $\mathrm{P}=0.463$ \\
\hline TT $(\mu \mathrm{mol} / \mathrm{L})$ & 0.593 & 193.05 & 33.3 & 83.3 & $\mathrm{P}=0.505$ \\
\hline NT/TT $(\mu \mathrm{mol} / \mathrm{L})$ & 0.620 & 86.73 & 55.6 & 83.3 & $\mathrm{P}=0.386$ \\
\hline Ds $(\mu \mathrm{mol} / \mathrm{L})$ & 0.630 & 14.60 & 55.6 & 83.3 & $\mathrm{P}=0.351$ \\
\hline Ds/NT $(\mu \mathrm{mol} / \mathrm{L})$ & 0.620 & 7.65 & 55.6 & 83.3 & $\mathrm{P}=0.386$ \\
\hline Ds/TT $(\mu \mathrm{mol} / \mathrm{L})$ & 0.620 & 6.63 & 55.6 & 83.3 & $\mathrm{P}=0.386$ \\
\hline IMA $(\mathrm{ABSU})$ & 0.787 & 1.25 & 72.2 & 83.3 & $\mathrm{P}=0.039$ \\
\hline ALB $(\mathrm{g} / \mathrm{L})$ & 0.671 & 7.70 & 83.3 & 83.3 & $\mathrm{P}=0.217$ \\
\hline
\end{tabular}

NT - native thiol, TT - total thiol, Ds - disulfide, IMA - ischemia-modified albumin, ABSU - absorbance units, ALB - albumin


Fig. 1. ROC curve analysis of thiol/disulfide homeostasis parameters 

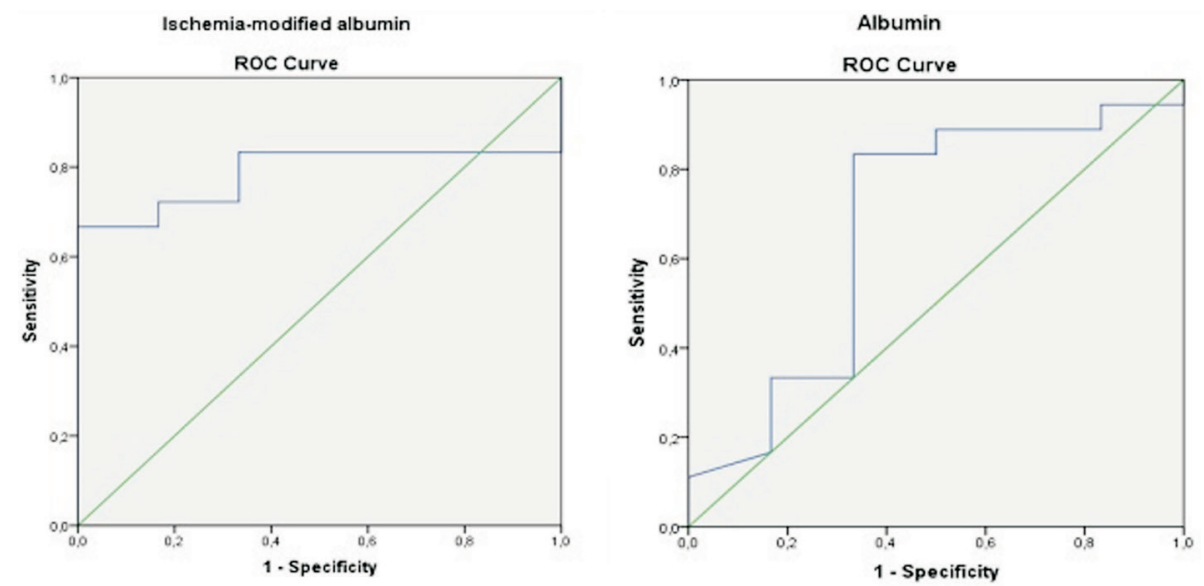

Fig. 2. ROC curve analysis of ischemia-modified albumin and albumin levels

\section{Discussion}

What are the factors that are included in the checklist to evaluate the pathogenesis of a disease? It is possible to count many, such as the virulence of the agent, host immunity, hormones, and genetic factors, etc. One of the constituents of this list is oxidative stress, which was the main concern of this study. Oxidative stress can be defined simply as a disruption in the homeostasis between the number of reactive oxygen species (free radicals) and antioxidant compounds (BETTERIDGE, 2000). In veterinary medicine, oxidative stress has been studied in many diseases of dogs, such as demodicosis (ROMANUCCI et al., 2011), atopic dermatitis (KAPUN et al., 2012), Hepatozoon canis (KİRAL et al., 2005), cardiac disease (FREEMAN et al., 2005), kidney disease (GALVÃO, 2009), and malignant mammary neoplasms (ASKAR et al., 2009). In these studies, only some of the oxidative stress markers, namely plasma MDA, total antioxidant capacity (TAC), whole blood glutathione peroxidase (GPX) and erythrocyte superoxide dismutase (SOD) were employed. In our study, we tried to analyse the relationship between oxidative stress and canine distemper based on IMA and the newly developed marker $T D H$, since this viral disease is characterized by intense oxidative stress.

Canine distemper is a multi-systemic and severe immunosuppressive disease of dogs (SUMMERS and APPEL, 1985), with serious clinical signs which affect the respiratory, digestive and nervous systems (BEINEKE et al., 2009). The virus replication and intense oxidative stress lead to multifocal demyelinating lesions in the grey and white matters of the brain (SUMMERS and APPEL, 1985). The pathology of canine distemper is related to ROS accumulation (VANDEVELDE and ZURBRIGGEN, 2005). KARADENIZ et al. (2008) reported that the concentration of oxidative stress markers (malondialdehyde [MDA], nitrates, nitrites, and ceruloplasmin) increased and the concentration of antioxidant compounds (glutathione [GSH], ascorbate, retinol, and $\beta$ carotene) declined in dogs with canine distemper. To the best of our knowledge, there is only one study in veterinary medicine on using TDH levels in the evaluation of oxidative stress in calves (ERDOĞAN et al., 2019). No studies were found relating to dogs on this subject. This is the first study that evaluates the plasma IMA levels and TDH in dogs with canine distemper.

Thiols, antioxidant molecules, constitute one of the important links in the chain of the extracellular defence system (ATMACA, 2004; EREL and NESELIOGLU, 2014; OZKAN et al., 2002). The proteins in the cell wall and the extracellular fluid are oxidized by the cysteine residue of the thiols in the presence of oxidant molecules (GO and JONES, 2011). Thiols are metabolized into disulfide bonds in this reversible reaction (EREL and NESELIOGLU, 
2014). The thiol/disulfide balance is an important factor in the regulation of the cell cycle (TURELL et al., 2013). Knowing the function of thiols in the antioxidant system is becoming increasingly important in understanding the connection between various diseases and oxidative stress. Recently, thiol/disulfide homeostasis has been investigated in a wide variety of human diseases, such as respiratory diseases (BABAOGLU et al., 2016), Alzheimer's disease (GUMUSYAYLA et al., 2016), diabetes mellitus (ATES et al., 2016), pre-eclampsia (OZLER et al., 2015), and coronary heart disease (ALTIPARMAK et al., 2016). In studies performed on obese children (ELMAS et al., 2017) and people with pancreatitis (KÖSEOĞLU et al., 2018), Ds/ NT and Ds/TT ratios were found to be significantly higher, but NT, TT levels and NT/TT ratios to be significantly lower. In another study on people with chronic obstructive pulmonary disease (EROĞLU et al., 2018), NT, TT levels and the NT/TT ratio were observed to be significantly lower, whereas Ds/NT and Ds/TT ratios were found to be significantly higher. Additionally, an ostensibly negative correlation was detected between antioxidant and oxidant parameters. In a study conducted by KAYA et al. (2016) on patients with childhood asthma; Ds level, Ds/NT and Ds/TT ratios were noted to be significantly higher. The thiol/disulfide balance was also investigated in a study of veterinary medicine on calves. This rare study revealed low levels of NT and TT parameters in calves treated with hot-iron disbudding (ERDOĞAN et al., 2019).

Along the same lines as these studies, our study demonstrated that antioxidant markers of TDH (NT, TT levels, and NT/TT ratio) decreased, whereas oxidant markers of Ds level, and Ds/NT and Ds/TT ratios increased in the $\mathrm{CD}$ group compared to the control group. Some studies have shown that the products of oxidative stress generated new radicals by removing protons from various molecules, such as thiols and fatty acids (AKBAS et al., 2017; ÖZCAN et al., 2015; YIN and PORTER, 2011). Therefore, a decrease in plasma thiol concentration was considered to be an indicator of oxidative stress and increased ROS production (AKBAS et al., 2017). These findings demonstrated that changes in $\mathrm{TDH}$ were in favour of oxidants in dogs with canine distemper. Moreover, these findings further indicate that oxidative stress had increased and the organism was consuming thiols to combat the increased oxidative stress.

Ischemia-modified albumin is an oxidant marker which is a derivative of albumin (LIPPI and MONTAGNANA, 2009). In human medicine, many studies are available on the relationship between IMA and increased oxidative stress. ÖZCAN et al. (2018) reported that IMA levels were higher in sickle cell disease. EROGLU et al. (2018) observed a significant elevation in IMA levels in patients with chronic obstructive pulmonary disease (COPD) compared to the control group. They indicated that the levels of IMA were positively correlated with other oxidant parameters (Ds, Ds/NT, and Ds/TT) and negatively correlated with antioxidant parameters (NT, TT, and NT/TT). Similarly, our results showed that IMA levels were significantly higher in the $\mathrm{CD}$ group $(\mathrm{P}<0.05)$, and there was a positive correlation with other oxidant parameters (Ds/NT and Ds/TT ratios), and a negative correlation with antioxidant parameters (NT, TT, and NT/TT). Besides, the areas under the ROC curve of IMA, Ds/NT, and Ds/TT were 0.78 , 0.62 , and 0.62 respectively. The overall diagnostic performances of IMA, Ds/NT, and Ds/TT for the detection of increased oxidative stress were similar. These findings demonstrated that a high level of IMA was associated with increased oxidative stress in the body, and Ds/NT and Ds/TT ratios can be used as signs of oxidative stress, but the overall diagnostic performance of IMA was superior to both Ds/NT and Ds/TT.

Albumin is a negative acute-phase protein that is known to decrease in concentration under inflammatory conditions in dogs (MARTINEZ SUBIELA and CERON, 2005) and it has a role in the elimination of ROS (LIPPI and MONTAGNANA, 2009). ÖZCAN et al. (2018) found that plasma albumin levels were lower in patients with sickle cell anaemia than those of the control group. They also suggested a strong positive correlation between albumin and native and total thiol. The present study demonstrated that the plasma albumin levels were lower in the $\mathrm{CD}$ group than the control group. It was further noted that plasma albumin levels 
were significantly positively correlated with plasma native and total thiol levels $(\mathrm{P}<0.01)$, but negatively correlated with plasma IMA levels and Ds/NT and Ds/TT ratios. In the CD group, high levels of IMA and Ds, high ratios of Ds/NT and Ds/TT, low NT and TT levels, and a low NT/TT ratio were interpreted as an increase in oxidative stress in dogs. Therefore, the low levels of albumin in the CD group can be explained by the acute-phase reaction and increased oxidative stress in dogs. Likewise, KINOSHITA et al. (2017) reported that low albumin levels were associated with increased oxidative stress. Additionally, the argument that albumin decreases with the increase in oxidative stress would confirm the positive correlation between NT and TT and the negative correlation with IMA, Ds/NT and Ds/TT.

In conclusion, it was observed that our findings were similar to those obtained in the aforementioned studies. One of the main aims of this study was to introduce the use of IMA and the newly developed marker TDH in evaluating oxidative stress in dogs with canine distemper. In this context, the antioxidant parameters (NT, TT) were apparently lower and the oxidant parameters (Ds, Ds/NT and Ds/TT) were higher, as expected. However, IMA levels were found to be significantly higher $(\mathrm{P}<0.05)$ and its area under the ROC curve was also greater than that of the other parameters. Therefore, it can be suggested that IMA prevailed over other oxidant parameters in determining increased oxidative stress. Moreover, the data further indicated that TDH changed in favour of oxidants, therefore it can also be a reasonable parameter in the evaluation of oxidative stress. Besides, the increase in the IMA and the decrease in the ALB levels also support these data. The rising ratios of Ds/NT and Ds/ TT correlated similarly with the increasing levels of IMA and the ROC areas were close to each other, which showed that they were compatible parameters in exhibiting increased oxidative stress. In this context, further studies should be carried out with well-known antioxidant parameters such as SOD, GPX, CAT, etc. to determine the superiority of the parameters in exhibiting oxidative stress. Data on the levels of oxidative biomarkers at different phases of canine distemper should also be investigated.

\section{Ethics Committee Approval}

Ethics committee approval was received for this study from the ethics committee of Atatürk University Faculty of Veterinary Medicine (2019/08).

\section{Conflicts of interest}

The author(s) declared no potential conflicts of interest concerning the research, authorship, and/or publication of this article.

\section{Funding}

The author(s) received no financial support for the research, authorship, and/or publication of this article.

\section{References}

AKBAS, A., F. KİLİNC, S. SENER, A. AKTAŞ, P. BARAN, M. ERGIN (2017): Investigation of thiol-disulphide balance in patients with acute urticaria and chronic spontaneous urticaria. Cutan. Ocul. Toxicol. 36, 205-210.

DOI: 10.1080/15569527.2016.1240179

ALTIPARMAK, I. H., M. E. ERKUŞ, H. SEZEN, R. DEMIRBAG, O. GUNEBAKMAZ, Z. KAYA, Y. SEZEN, R. ASOGLU, I. H. DEDEOGLU, S. NESELIOGLU, O. EREL (2016): The relation of serum thiol levels and thiol/ disulphide homeostasis with the severity of coronary artery disease. Kardiol Pol. 74, 1346-1353.

DOI: $10.5603 /$ KP.a2016.0085

ASKAR, T. K., B. SALMANOGLU, R. SALMANOGLU, N. ERKAL, A. BESKAYA (2009): Changes in oxidative status and trace element levels in dogs with mammary tumours. Acta Vet-Beograd. 59, 405-411.

ASOĞLU, M., F. KILIÇASLAN, Ö. BEGINOĞLU, Ü. FEDAİ, Ö. AKIL, H. ÇELİK, H. BÜYÜKASLAN (2018): Thiol/disulphide homeostasis as a new oxidative stress marker in untreated patients with generalized anxiety disorder. Anadolu Psikiyatr De. 19, 143-149.

DOI: 10.5455/apd.261956

ATES, I., M. KAPLAN, M. YUKSEL, D. MESE, M. ALISIIK, Ö. EREL, S. GULER (2016): Determination of thiol/ disulphide homeostasis in type 1 diabetes mellitus and the factors associated with thiol oxidation. Endocrine. 51, 4751.

DOI: $10.1007 / \mathrm{s} 12020-015-0784-6$

ATMACA, G. (2004): Antioxidant effects of sulfur-containing amino acids. Yonsei Med J. 45, 776-788.

DOI: 10.3349/ymj.2004.45.5.776

BABAOGLU, E., H. KİLİC, H. HEZER, O. DAG, E. PARLAK, A. SENTURK, A. KARALEZLİ, M. ALİSIK, O. EREL, H. C. HASANOGLU (2016): Comparison of thiol/disulphide homeostasis parameters in patients with COPD, asthma and ACOS. Eur Rev Med Pharmacol Sci. 20, 1537-1543. 
BEINEKE, A., C. PUFF, F. SEEHUSEN, W. BAUMGARTNER (2009): Pathogenesis and immunopathology of systemic and nervous canine distemper. Vet Immunol Immunopathol. 127, 1-18.

DOI: $10.1016 /$ j.vetimm.2008.09.023

BETTERIDGE, D. J (2000): What is oxidative stress? Metabolism. 49, 3-8.

BİLDİ, A., F. KARGIN, K. SEYREK, S. PASA, S. OZENSOY (2004): Oxidative stress and non-enzymatic antioxidative status in dogs with visceral Leishmaniasis. Res. Vet. Sci. 77, 63-66.

DOI: 10.1016/j.rvsc.2004.01.005

BISWAS, S., A. S. CHIDA, I. RAHMAN (2006): Redox modifications of protein-thiols: emerging roles in cell signaling. Biochem. Pharmacol. 71, 551-564.

CARPENTER, M. A., M. J. APPEL, M. E. ROELKE-PARKER, L. MUNSON, H. HOFER, M. EAST, S. J. O'BRIEN (1998): Genetic characterization of canine distemper virus in Serengeti carnivores. Vet Immunol Immunopathol. 65, 259-266.

CIRCU, M. L., T. Y. AW (2010): Reactive oxygen species, cellular redox systems, and apoptosis. Free Radic Biol Med. 48, 749-762.

DOI: 10.1016/j.freeradbiomed.2009.12.022

DAŞ, M., Y. ÇEVİK, Ö. EREL, Ş. K. ÇORBACIOĞLU (2016): Ischemia-modified albumin levels in the prediction of acute critical neurological findings in carbon monoxide poisoning. Kaohsiung J Med Sci. 32, 201-206.

DOI: 10.1016/j.kjms.2016.03.006

ELMAS, B., M. KARACAN, P. DERVIŞOĞLU, M. KÖSECİK, Ş. P. ISSÜUEN (2017): Dynamic thiol/disulphide homeostasis as a novel indicator of oxidative stress in obese children and its relationship with inflammatorycardiovascular markers. Anatol. J. Cardiol. 18, 361-369.

DOI: 10.14744/AnatolJCardiol.2017.7740

ERDOĞAN, H., İ. ÇAMKERTEN, G. ÇAMKERTEN, K. URAL, S. ERDOĞAN, İ. GÜNAL, Ö. EREL (2019): The effect of hot-iron disbudding on thiol-disulphide homeostasis in calves. Kafkas Univ Vet Fak Derg. 25, 335339 (in Turkish)

DOI: $10.9775 / \mathrm{kvfd} .2018 .20950$

EREL, O., S. NESELİOGLU (2014): A novel and automated assay for thiol/disulphide homeostasis. Clin. Biochem. 47, 326-332.

DOI: 10.1016/j.clinbiochem.2014.09.026

EROĞLU, O., N. D. BADEM, A. BACCIOĞLU, E. CÖMERTPAY, S. NEȘELIOĞLU, Ö. EREL (2018): Significance of thiol/disulphide homeostasis and ischemia modified albumin levels in chronic obstructive pulmonary disease. European Res. J. 5, 250-257.

DOI: $10.18621 /$ eurj.425178

FREEMAN, L. M., J. E. RUSH, P. E. MILBURY, J. B. BLUMBERG (2005): Antioxidant status and biomarkers of oxidative stress in dogs with congestive heart failure. J. Vet. Intern. Med. 19, 537-541.

GALVÃO, A. L. B (2009) Estresse oxidativo nos estágios finais da doença renal crônica em pequenos animais. Arch. Vet. Sci. 14, 178-186.

GO, Y. M., D. P. JONES (2011): Cysteine/cystine redox signaling in cardiovascular disease. Free Radic. Biol. Med. 50, 495-509.

DOI: $10.1016 /$ j.freeradbiomed.2010.11.029

GREENE, G., M. APPEL (1998): Canine Distemper Virus. In: Infectious Disease of the Dog and Cat. (Greene, G. E., Ed.), $2^{\text {nd }}$ ed., Saunders, Philadelphia, PA, pp. 1-22.

GUMUSYAYLA, S., G. VURAL, H. BEKTAS, O. DENIZ, S. NESELIOGLU, O. EREL (2016): A novel oxidative stress marker in patients with Alzheimer's disease: dynamic thioldisulphide homeostasis. Acta Neuropsychiatr. 28, 315-320. DOI: $10.1017 /$ neu.2016.13

HANIKOGLU, F., A. HANIKOGLU, E. KUCUKSAYAN, M. ALİSIK, A. A. GOCENER, O. EREL, M. BAYKARA, A. CUOGHİ, A. TOMASİ, T. OZBEN (2016): Dynamic thiol/disulphide homeostasis before and after radical prostatectomy in patients with prostate cancer. Free Radic. Res. 50, 79-84.

DOI: $10.1080 / 10715762.2016 .1235787$

KAPUN, A. P., J. SALOBIR, A. LEVART, T. KOTNIK, A. N. SVETE (2012): Oxidative stress markers in canine atopic dermatitis. Res. Vet. Sci. 92, 469-470.

DOI: $10.1016 /$ j.rvsc. 2011.04.014

KARADENIZ, A., B. HANEDAN, M. CEMEK, M. K. BÖRKÜ (2008): Relationship between Canine Distemper and Oxidative Stress in dogs. Rev. Med. Vet-Toulouse. 159, 462-467.

KAYA, B. K., M. AYDİN, M. M. DONMA, M. DEMIRKOL, C. BICER, O. EREL (2016): Association of thiol disulfide homeostasis with childhood asthma. J. Pediatr. Biochem. 6, 152-155.

DOI: $10.1055 / \mathrm{s}-0036-1597607$

KINOSHITA, H., K. WATANABE, T. AZMA, G. FENG, T. AKAHORI, H. HAYASHI, A. WAKATSUKI (2017): Human serum albumin and oxidative stress in preeclamptic women and the mechanism of albumin for stress reduction. Heliyon. 3, e00369.

DOI: 10.1016/j.heliyon.2017.e00369

KİRAL, F., T. KARAGENC, S. PASA, C. YENISEY, K. SEYREK (2005): Dogs with hepatozoon canis respond to the oxidative stress by increased production of glutathione and nitric oxide. Vet. Parasitol. 31, 15-21.

KÖSEOĞLU, H., M. ALIŞIK, M. BAŞARAN, Ö. T. YÜREKLİ, T. SOLAKOĞLU, M. TAHTACI, O. ERSOY, Ö. EREL (2018): Dynamic thiol/disulphide homeostasis in acute pancreatitis. Turk J. Gastroenterol. 29, 348-353. DOI: $10.5152 /$ tjg. 2018.17499 
KUMAR, A., J. P. VARSHNEY, R. C. PATRA (2006): A comparative study on oxidative stress in dogs infected with Ehrlichia canis with or without concurrent infection with Babesia gibsoni. Vet. Res. Commun. 30, 917-920.

DOI: $10.1007 / \mathrm{s} 11259-006-3365-6$

LIPPI, G., M. MONTAGNANA (2009): Ischemia-modified albumin in ischemic disorders. Ann. Thorac. Cardiovasc. Surg. 15, 137.

MARTELLA, V., G. ELIA, C. BUONAVOGLIA (2008): Canine distemper virus. Vet. Clin. North Am. Small Anim. Pract. 38, 787-797.

MARTINEZ-SUBIELA, S., J. CERON (2005): Evaluation of acute phase protein indexes in dogs with leishmaniasis at diagnosis, during and after short-term treatment. Vet. Med.-Czech. 50, 39-46.

MURASE, T., T. UEDA, O. YAMATO, M. TAJIMA, Y. MAEDE (1996): Oxidative damage and enhanced erythrophagocytosis in canine erythrocytes infected with Babesia gibsoni. J. Vet. Med Sci. 58, 259-261.

ÖZCAN, O., H. ERDAL, G. ÇAKIRCA, Z. YÖNDEN (2015): Oxidative stress and its impacts on intracellular lipids, proteins and DNA. J. Clin. Exp. Invest. 6, 331-336.

ÖZCAN, O., H. ERDAL, G. İLHAN, D. DEMIR, A. B. GÜRPINAR, S. NEŞELIOĞLU, Ö. EREL (2018): Plasma ischemia-modified albumin levels and dynamic thiol/ disulfide balance in Sickle Cell Disease: a case-control study. Turk J. Hematol. 35, 265.

OZKAN, Y., E. OZKAN, B. SIMSEK (2002): Plasma total homocysteine and cysteine levels as cardiovascular risk factors in coronary heart disease. Int. J. Cardiol. 82, 269277.

DOI: $10.1016 / \mathrm{s} 0167-5273(02) 00010-4$

OZLER, S., O. EREL, E. OZTAS, A. O. ERSOY, M. ERGIN, A. SUCAK, N. DANISMAN (2015): Serum thiol/disulphide homeostasis in Preeclampsia. Pregnancy. 34, 474-485.

DOI: $10.3109 / 10641955.2015 .1077859$

PANDA, D., R. C. PATRA, S. NANDI, D. SWARUP (2009): Oxidative stress indices in gastroenteritis in dogs with canine parvoviral infection. Res. Vet. Sci. 86, 36-42.

DOI: $10.1016 /$ j.rvsc.2008.05.008
ROMANUCCI, M., L. BONGIOVANNI, A. RUSSO, S. CAPUCCINI, L. MECHELLI, L. ORDEIX, L. D. SALDA (2011): Oxidative stress in the pathogenesis of canine zincresponsive dermatosis. Vet. Dermatol. 22, 31-38.

SEMBA, R. D., A. M. TANG (1999): Micronutrients and the pathogenesis of human immunodeficiency virus infection. Br. J. Nutr. 81, 181-189.

SUMMERS, B. A., M. APPEL (1994): Aspects of canine distemper virus and measles virus encephalomyelitis. Neuropath. Appl. Neuro. 20, 525-534.

SUMMERS, B. A., M. J. APPEL (1985): Syncytia formation: an aid in the diagnosis of canine distemper encephalomyelitis. J. Comp. Pathol. 95, 425-435.

TAYLOR, S. (2009): Encephalitis, myelitis and meningitis. In: Small Animal Internal Medicine. (Couto, C. G., R. W. Nelson, Eds.), th $^{\text {th }}$ ed., Mosby Elsevier, St. Louis, Missouri, pp. 1059-1062.

THULIN, J. D., D. E. GRANSTROM, H. B. GELBERG, D. G. MORTON, R. A. FRENCH, R. C. GILES (1992): Concurrent protozoal encephalitis and canine distemper virus infection in a raccoon (Procyon lotor). [Case Reports]. Vet. Rec. 130, 162-164.

TURELL, L., R. RADI, B. ALVAREZ (2013): The thiol pool in human plasma: the central contribution of albumin to redox processes. Free Radic. Biol. Med. 65, 244-253.

DOI: 10.1016/j.freeradbiomed.2013.05.050

VANDEVELDE, M., A. ZURBRIGGEN (2005): Demyelination in canine distemper virus infection: a review. Acta Neuropathol. 109, 56-68.

DOI: $10.1007 /$ s00401-004-0958-4

WILLIAMS, E. S. (2001): Canine Distemper. In: Infectious Diseases of Wild Mammals. (Williams, E. S., I. K. Barker, Eds.), Iowa State University Press, Iowa, pp. 50-59.

WRIGHT, N. G., H. J. CORNWELL, H. THOMPSON, I. M. LAUDER (1974): Canine distemper: current concepts in laboratory and clinical diagnosis. [Review]. Vet. Rec. 94, 86-92.

YIN, H., L. XU, N. A. PORTER (2011): Free radical lipid peroxidation: mechanisms and analysis. Chem. Rev. 111, 5944-5972.

DOI: $10.1021 / \mathrm{cr} 200084 \mathrm{z}$ 


\section{DEĞIRMENÇAY, Ş., G. ÇAMKERTEN, İ. ÇAMKERTEN, M. S. AKTAÇ: Istraživanje tiol-disulfidne} homeostaze i razine albumina modificiranog ishemijom radi procjene oksidacijskog stresa u pasa sa štenećakom. Vet. arhiv 91, 39-49, 2021.

\section{SAŽETAK}

U ovom je radu istraživana dijagnostička vrijednost tiol-disulfidne homeostaze (TDH) i razine albumina modificiranog ishemijom (IMA) u procjeni oksidacijskog stresa u pasa sa štenećakom. Uključena su 24 psa križanca: 18 pasa sa štenećakom (skupina CD) i 6 zdravih pasa koji su bili kontrolna skupina. U obje su skupine uzeti uzorci krvi za analizu antioksidacijskih i oksidacijskih pokazatelja. Osim TDH pokazatelja (razine nativnog tiola [NT], ukupnog tiola [TT] i disulfida [Ds] te omjeri Ds/NT, Ds/TT i NT/TT), u krvnom serumu obiju skupina određeni su i IMA te albumin (ALB). Razine IMA-e u CD skupini bile su znakovito veće nego u kontrolnoj skupini $(\mathrm{P}<0,05)$. Antioksidacijski pokazatelji (NT, TT) i oksidacijski pokazatelji (Ds, Ds/NT i Ds/TT) pokazali su međusobnu znakovitu pozitivnu korelaciju $(\mathrm{P}<0,01)$. Područja ispod ROC krivulje IMA-e, Ds/NT i Ds/TT bila su 0,78, 0,62 i 0,62. Najviše razine IMA-e, Ds, Ds/NT i Ds/TT te niske razine NT-a, TT-a, NT/TT-a i ALB-a u pasa sa štenećakom mogu se upotrijebiti u procjeni oksidacijskog stresa uzrokovanog tom bolešću. Ukupno gledano, dijagnostička svojstva IMA-e, Ds/NT, i Ds/TT za otkrivanje povećanog oksidacijskog stresa bila su slična, s tim da je najprikladniji bio IMA.

Ključne riječi: štenećak; oksidacijski stres; tiol-disulfidna homeostaza; albumin modificiran ishemijom 
